\title{
Indigenous country in the southwest Gulf of Carpentaria: Territories of difference or indifference?
}

\section{Seán Kerins and Jacky Green}

To remove the passive welfare trap, we need to break the nexus between indigenous development and geography. This means reorienting programs and incentives onto the development of individuals, rather than the development of geographical areas. It is a vital distinction (Tudge 2011: 22).

\section{Introduction}

The Abbott government is seeking to sever Indigenous peoples' cultural, spiritual and economic relationships with their land and other natural resources, while also breaking down Indigenous social relationships and kin structures. We are told this is being done 'to remove the passive welfare trap'. Facilitating the involuntary mobility of Indigenous Australians off their ancestral lands to areas where better education and job opportunities exist is not new. It was also one of the underlying principles of the 2008 Council of Australian Government's National Indigenous Reform Agreement (Closing the Gap) (COAG 2008: E-79). 
It is also evident in the recent Forrest review: creating parity which, in Chapter 8, champions the break-up of Indigenous common property, along with the movement of Indigenous peoples off their country (Forrest 2014: 220). Forrest tells Indigenous peoples what success looks like for their remote communities. He says, 'remote communities are safe, vibrant and positive environments and local people and community members are able to orbit to larger town centres to take up work' (Forrest 2014: 191).

The idea, promoted by Australian governments and the economic elite, that Indigenous peoples should surrender their hard-won common property resources and abandon their ancestral lands to seek work elsewhere, is a view that Garawa, Gudanji, Marra, Waanyi and Yanyuwa peoples of the southwest Gulf of Carpentaria in the Northern Territory (Fig. 9.1) reject in their approach to development. Instead, they see development as a nexus between themselves, as Indigenous peoples, and their country, where their common property resources, networks, culture and ecological knowledge serve as reservoirs of creative alternatives to state development projects (Green et al. 2012).

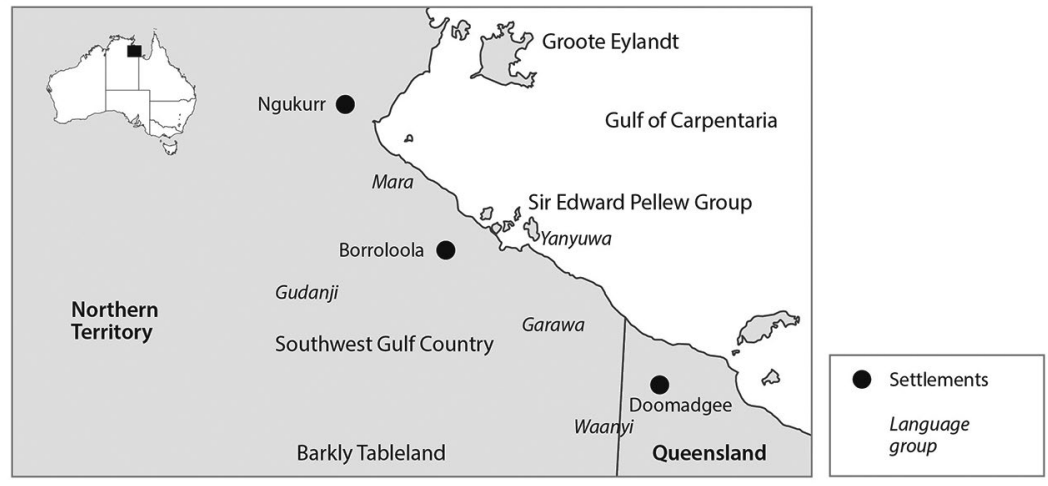

Fig. 9.1 Map showing Indigenous peoples of the southwest Gulf of Carpentaria

Source: Seán Kerins

\section{The failure of top-down policy}

Indigenous peoples in the Gulf region see the present structures and processes, which attempt to fit Indigenous interests to frameworks developed by the state, as not working and something that will 
not work for them. Many see current government policy, such as attenuating the communal attachment to land by individualising land ownership, as nothing more than government attempts to further alienate them from their country and kin and squash their long resistance to settler colonialism. They fear that if they are 'yarded up like cattle' and forced 'to live like white man in town with no culture' (Kerins 2013a) they will not be able to protect their country from the negative effects of large-scale development.

Over the past decade across the southwest Gulf region in the Northern Territory there has been a substantial increase in mining and energy resource extraction developments with few benefits flowing to Indigenous peoples, while it is they who bear the costs. Garawa, Gudanji, Marra, Waanyi and Yanyuwa peoples are alarmed at the increased environmental destruction and contamination of their country that they are witnessing (see Fig. 9.2 and Fig. 9.3). They are alarmed that species they once hunted, fished and gathered are quickly disappearing and that many of their important fishing and hunting places are now off limits because of access restrictions or pollution (Bardon 2014). They are increasingly alarmed that they cannot make their voice heard in the development debate. They are also alarmed that their long-term life project of living on and caring for country, which is 'embedded in local histories and encompassing visions of the world and the future that are distinct from those embodied by projects promoted by the state and markets' (Blaser 2004: 26), is being snuffed out.

It is important to remember that moving people off their country and usurping their land and other natural resources is not new to Indigenous peoples in the Gulf (see Fig. 9.4). 'The logic of elimination' (Wolfe 2006: 388) began in the 1870s when settler colonisers attempted to clear the land of Indigenous people with guns, poison and intimidation to make way for the first wave of European capital (Roberts 2005). It continued through to the 1960s when 133 Yanyuwa people were forcibly removed by the Welfare Branch from Borroloola to a reserve area (Dangana) $150 \mathrm{~km}$ east of Borroloola (Baker 1999: 99-100). 
ENGAGING INDIGENOUS ECONOMY

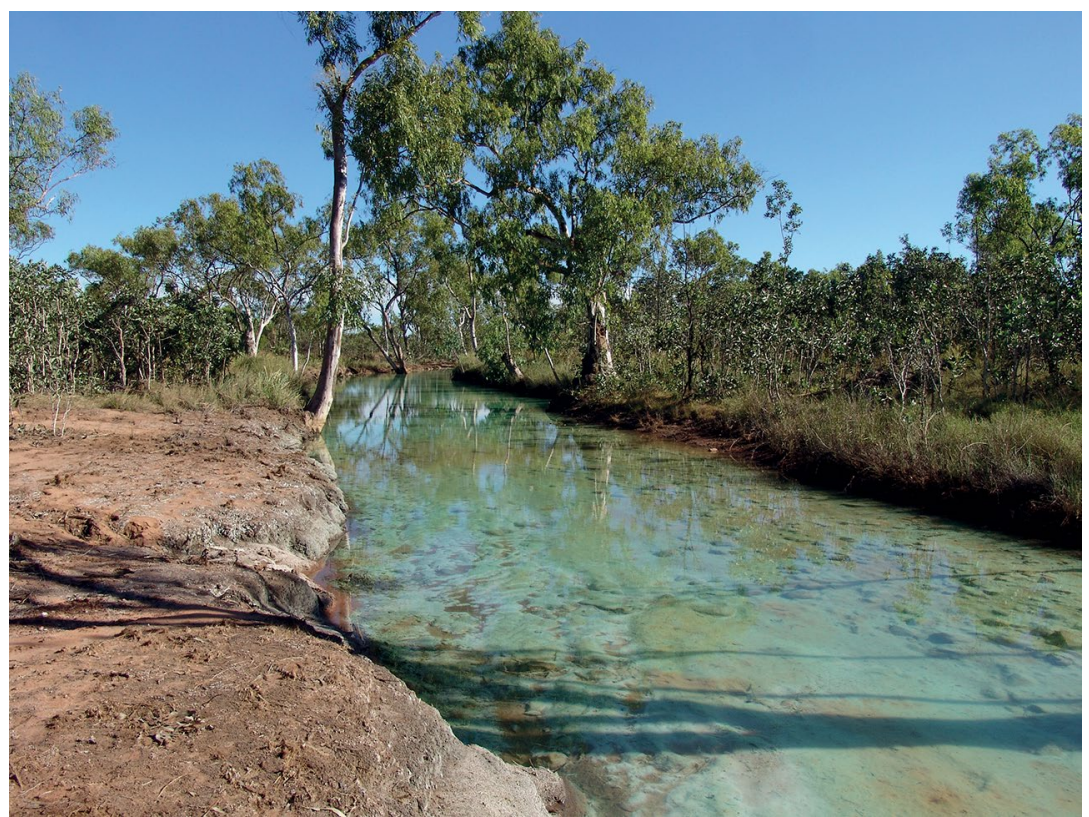

Fig. 9.2 Copper sulphide from Redbank mine flows directly into Hanrahan's Creek killing all aquatic life

Photo: Jessie Boylan

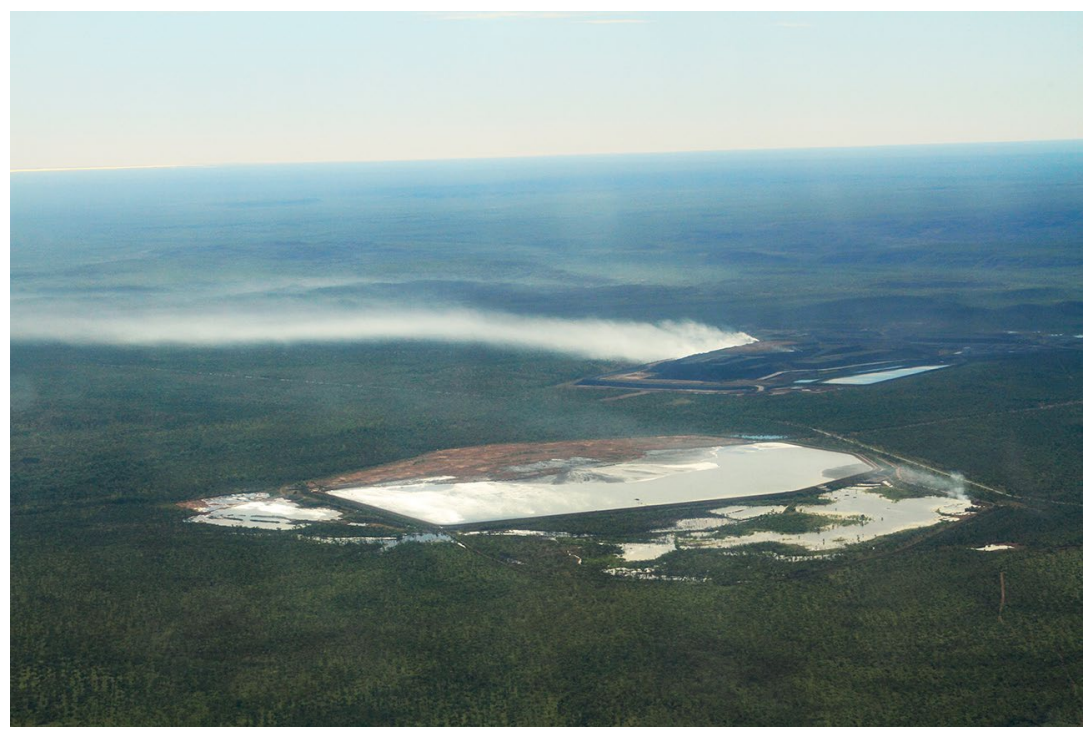

Fig. 9.3 Sulphur dioxide billowing from McArthur River Mine

Photo: David Morris 


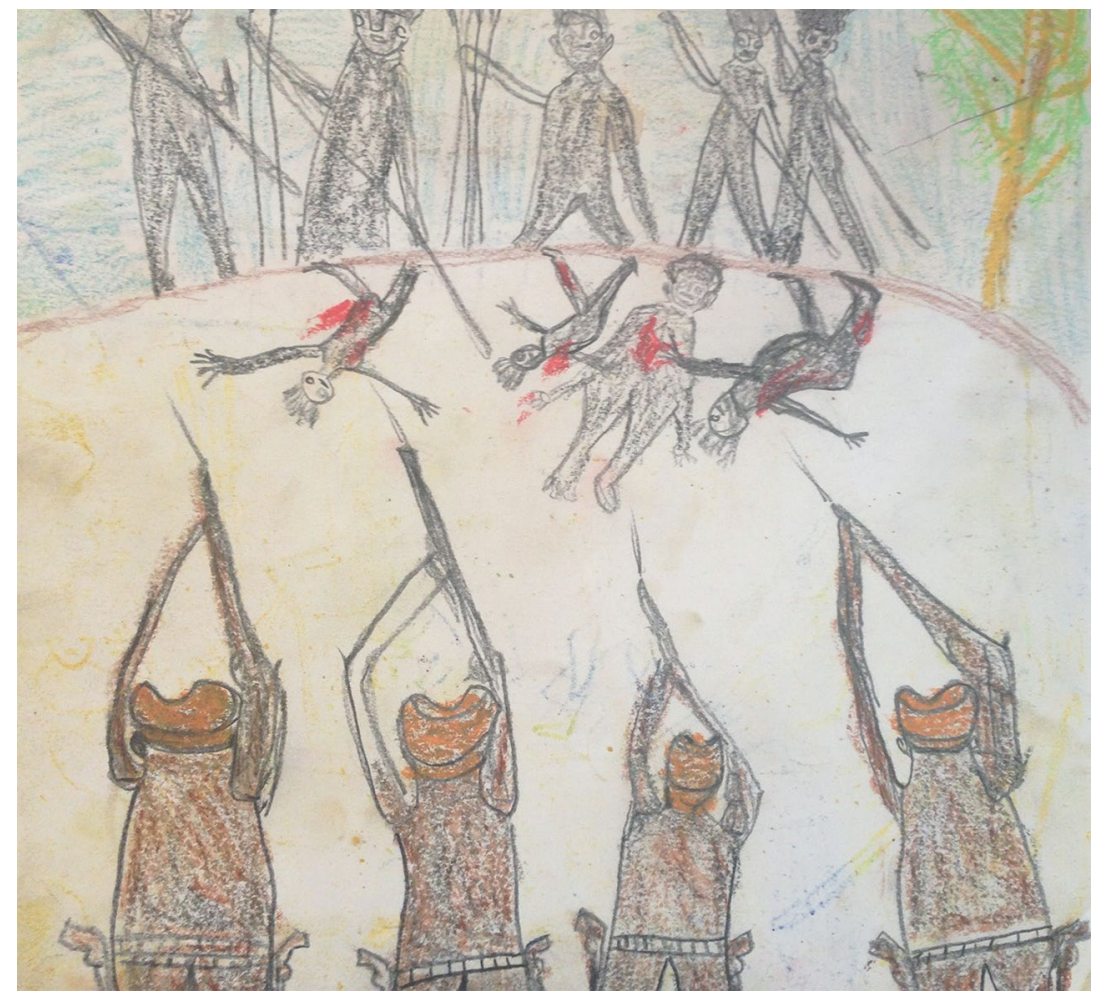

Fig. 9.4 Drawing of settler colonial violence in the Gulf Country, Dinny McDinny, (1927-2003)

Source: Private collection

As Wolfe (2006: 388) reminds us, the settler invasion is a structure rather than 'an event'. Jacky Green makes the same point in his artwork Same story, settlers-miners (Fig. 9.5), about which Green says:

It's not the first time we had people invade our country. It happened first time when whitefellas came with their packhorses, looking round to see what was there. Aboriginal people were watching from a distance, staying back, not wanting to be seen. Others were ready to spear them. The invasion is happening again. This time they come with their 'agreements' and their dozers. 


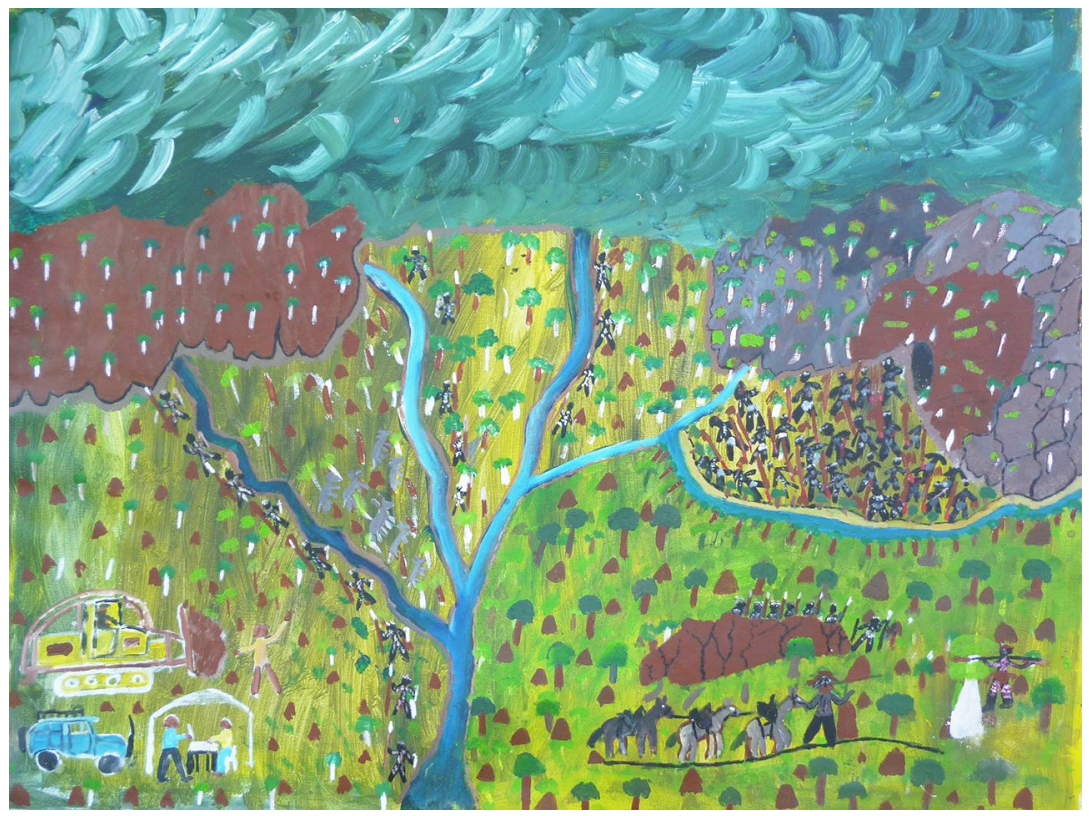

Fig. 9.5 Same story, settlers-miners, Jacky Green, 2013

Source: Private collection

\section{The success of Indigenous cultural and natural resource management}

For the past decade, in this very remote and challenging region (Fig. 9.6), Indigenous peoples have been highly successful in building small-scale cultural and natural resource management enterprises, utilising their common property resources, cultural knowledge and kinship networks to provide social, economic and environmental benefits to themselves and wider Australia. It is important to note that these projects all have roots in the much maligned Community Development Employment Projects (CDEP) scheme (Kerins 2012a). 


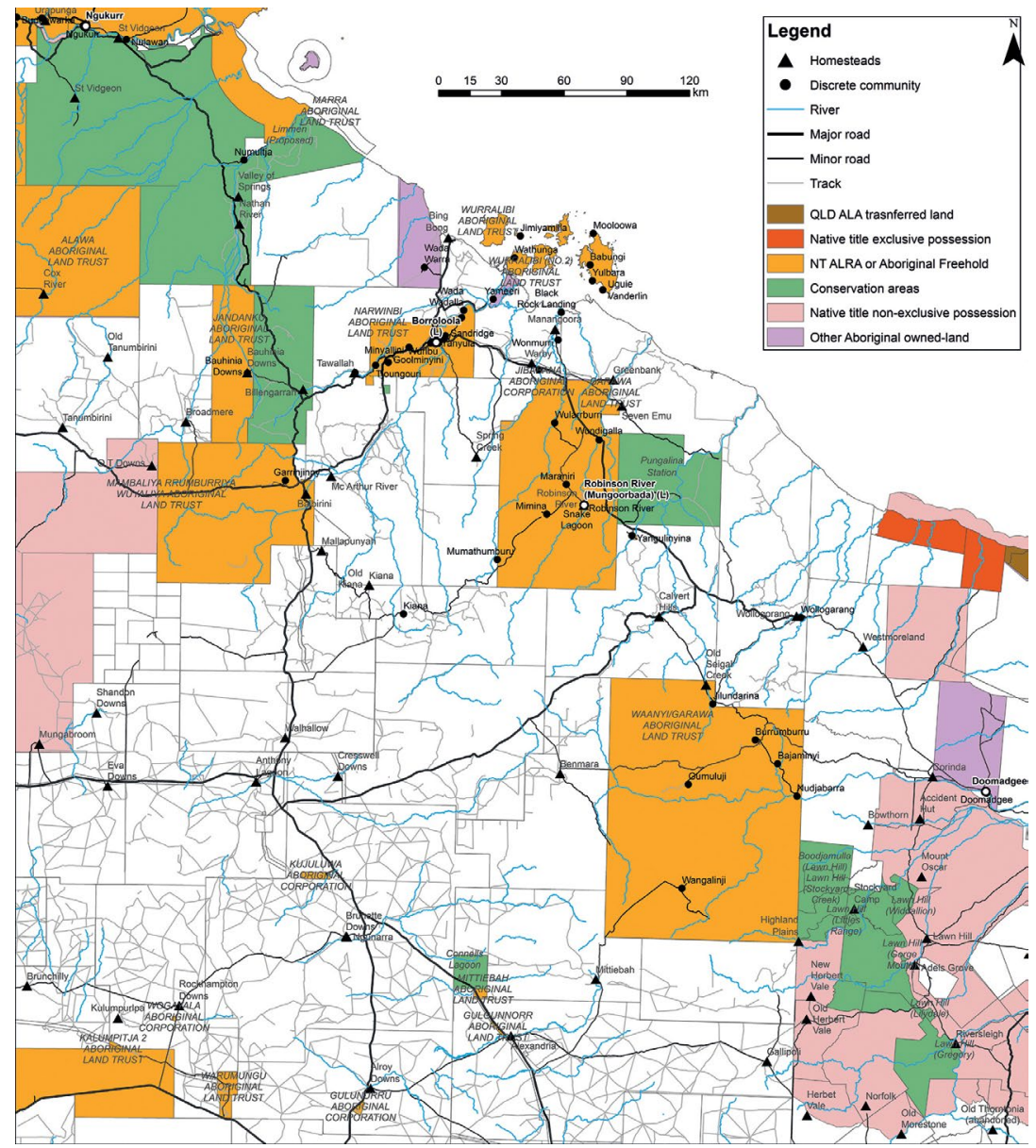

Fig. 9.6 Land tenure in the southwest Gulf of Carpentaria

Source: Francis Markham

Yanyuwa people operate a sea country ranger program employing 17 people through the Working on Country program. They recently declared their country an Indigenous Protected Area (IPA) where they focus, amongst other things, on creating meaningful employment opportunities for community members, managing important turtle and dugong breeding and feeding areas, fee for service work with fisheries, the removal of feral cats from the off-shore islands, and the transfer of cultural knowledge between generations (Yanyuwa Families et al. 2011). They are also engaging with market opportunities by developing an innovative cultural tourism enterprise based on wildlife in the region along with their cultural knowledge. If their property 
rights to fisheries resources were recognised by the Australian state, they would be able to pursue further opportunities, especially in the lucrative sports fisheries market. ${ }^{1}$

Garawa and Waanyi operate two ranger groups with seven fulltime rangers and up to 40 casual workers. However, the flexibility of employing casual workers is fast disappearing under recent government employment policy (Green et al. 2012). Over the past decade Garawa and Waanyi rangers and landowners have taken control of fire, replacing the boom and bust cycle of wildfires with an early dry season mosaic burning regime which has seen a considerable reduction in greenhouse gas emissions (see Fig. 9.7). They have also reconnected many young people with their country, bringing them to camps to participate in burning activities, planning meetings and fauna surveys (Kerins 2012b). They have also developed a plan of management for an IPA over the Waanyi/Garawa Aboriginal Land Trust - the Ganalanga Mindibirrina Indigenous Protected Area- to help expand their work activities, engage young people, create more employment, and develop enterprises such as cultural tourism and carbon farming (Gambold \& Kerins 2013).

To date, Gudanji and Marra have not been able to organise to develop formalised cultural and natural resource management activities on their country.

1 It is estimated that each year over 10,000 people fish in the saltwater country of the Yanyuwa people in the delta region of McArthur River and the coastal waters surrounding the Sir Edward Pellew Island Group. With little recognition of their property rights to fisheries, other than a non-commercial right recognised in the Native Title Act 1993 (Cwlth), Yanyuwa people are excluded from market opportunities. 


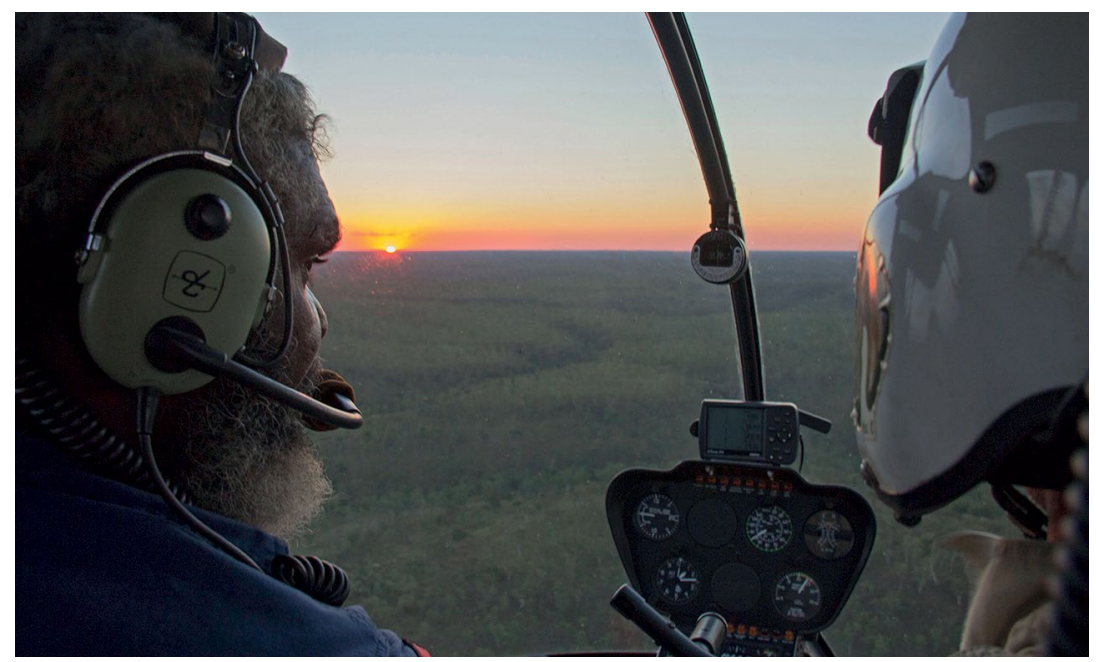

Fig. 9.7 Garawa ranger Donald Shadforth undertaking aerial controlled burning of his country at Robinson River

Source: Michael Lawrence-Taylor

\section{Building social enterprise}

For the past two years Garawa, Gudanji, Marra, Waanyi and Yanyuwa peoples have also been collaborating to develop a regional governance institution to operate across the southwest Gulf region in the Northern Territory as a social enterprise (Kerins 2013b). Social enterprises are 'not based on utilitarian-economic models but rather an economic model in which resources provide for broader goals, economic, social, cultural and political' (Berkes \& Davidson-Hunt 2007: 211). This can include the creation of jobs and the strengthening of social capital by supporting people who have been inactive back into the wider activities of the community (Borzaga \& Defourny 2001). While social enterprises can have a profit motive, their primary aim is to provide social and/or environmental dividends to community members, and in some cases to the wider public. They rarely distribute financial profit to individuals, with any surplus being reinvested for the long-term benefit of the community (Pearce 2003).

Garawa, Gudanji, Marra, Waanyi and Yanyuwa peoples aim, through establishing a regional governance institution, to break from the practice of relying entirely on government funding rounds for operational 
funds and move toward financial self-determination. They also intend to formalise their relationships with, and draw on the skills, expertise and financial contacts of, conservation and philanthropic organisations operating both nationally and internationally so that they can achieve their long-term development goal of sustainable land- and sea-based livelihoods throughout the region.

\section{Government policy}

Government support for these successful Indigenous cultural and natural resource management initiatives remains risk averse. Within the wider Indigenous policy framework they have been consigned, until recently, to the Australian Government's environment portfolio, where they were reliant predominantly on the IPA and Working on Country programs, as well as myriad other competitive short-term grant schemes (Kerins 2012b). The social, cultural, economic and environmental benefits they provide Indigenous groups and wider Australia were largely overlooked within the COAG Indigenous policy framework. The National Indigenous Reform Agreement (Closing the Gap) focused on 'the mainstream economy - real jobs, business opportunities, economic independence and wealth creation' (COAG 2008: 7).

There is also little evidence in the Northern Territory Government's Indigenous policy framework of its support for community-based enterprises operating across the Northern Territory. For example, the Northern Territory Government's Draft Indigenous Economic Development Strategy, in replicating the Australian Government's Indigenous Economic Development Strategy (Altman 2011), narrowly equates Indigenous economic development solely with increasing monetary wealth.

It states:

While the definition of wealth in an Indigenous context encompasses financial wealth, connection to land, family and holistic health (physical, spiritual and emotional), the draft Indigenous Economic Development Strategy 2013-2020 refers to financial wealth (Northern Territory Government 2013: 1).

The Australian and Northern Territory governments are using the project of 'Northern Development' and their Indigenous economic development strategies as policy tools, not so much to assist 
Indigenous peoples to achieve their own development aspirations, but as a legitimising strategy for their 'open for business' developmental agendas (Bevage 2013).

What we are witnessing across northern Australia is neoliberalism, which 'is the intensification of the influence and dominance of capital; it is the elevation of capitalism, as a mode of production, into an ethic, a set of political imperatives, and a cultural logic. It is also a project: a project to strengthen, restore, or in some cases, constitute anew the power of economic elites' (Thompson 2005: 23).

Jacky Green's provocative painting FIFO — Fly In Fuck Off (Fig. 9.8) captures something that many of us never see, the Aboriginal experience of dealing with state officials and mining company representatives in remote regions of the continent. It gives us a rare glimpse of the power relationship from an Aboriginal viewpoint. Green's artwork details how these meetings unfold after the planes arrive.

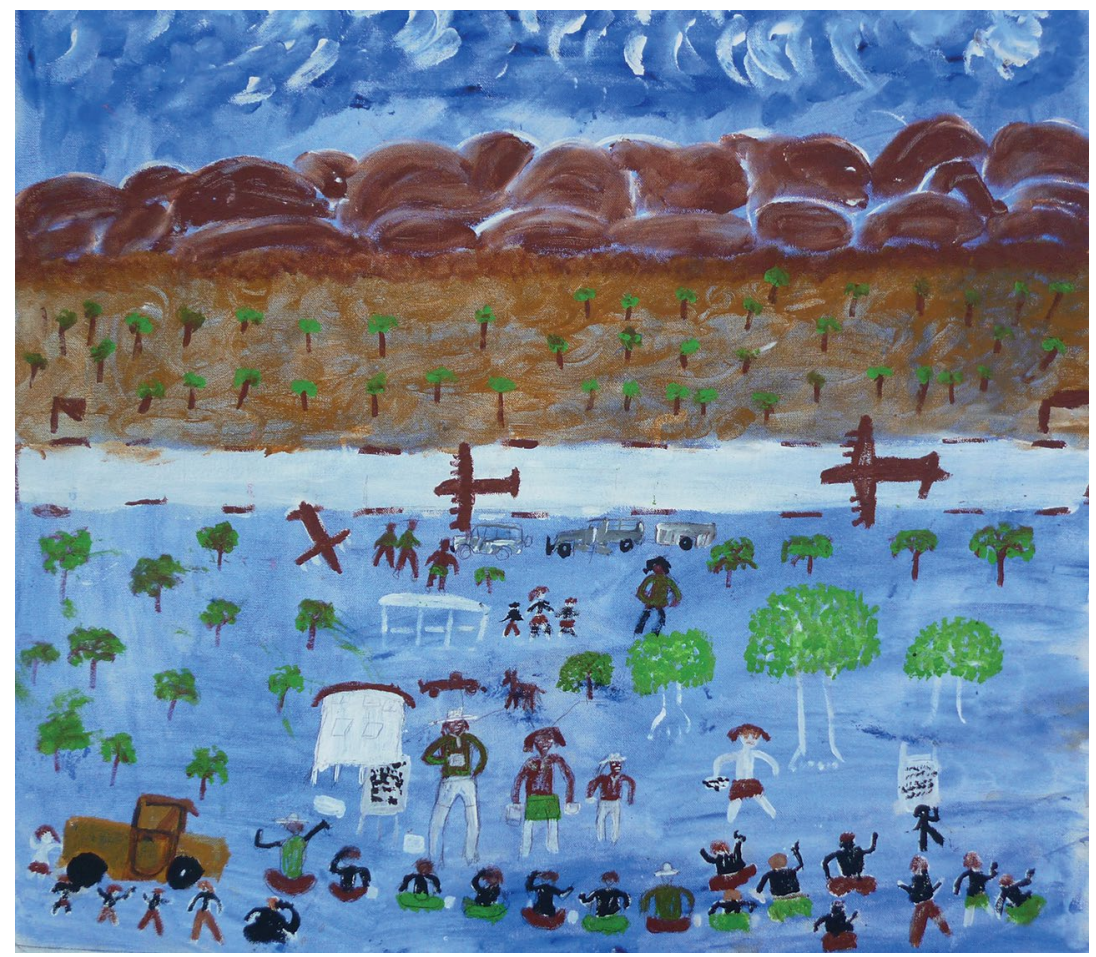

Fig. 9.8 FIFO-Fly In Fuck Off, Jacky Green, 2013

Source: Private collection 
He says of his artwork:

Aboriginal people sitting on the ground all focused on government and mining people standing with their whiteboard using complicated words. But we not really understanding, not getting our heads around what it really means. That's why some of them just sittin' there, on the ground, scratchin' their heads, and others got their hands up wantin' to ask questions. They just put something in front of us and when they think they got it right, they outta here. They just fly in and fuck off and we don't know what they really meant.

In Whitefellas work like white ants (Fig. 9.9), Green visualises the state's obsession with the individual as the death knell for Indigenous peoples.

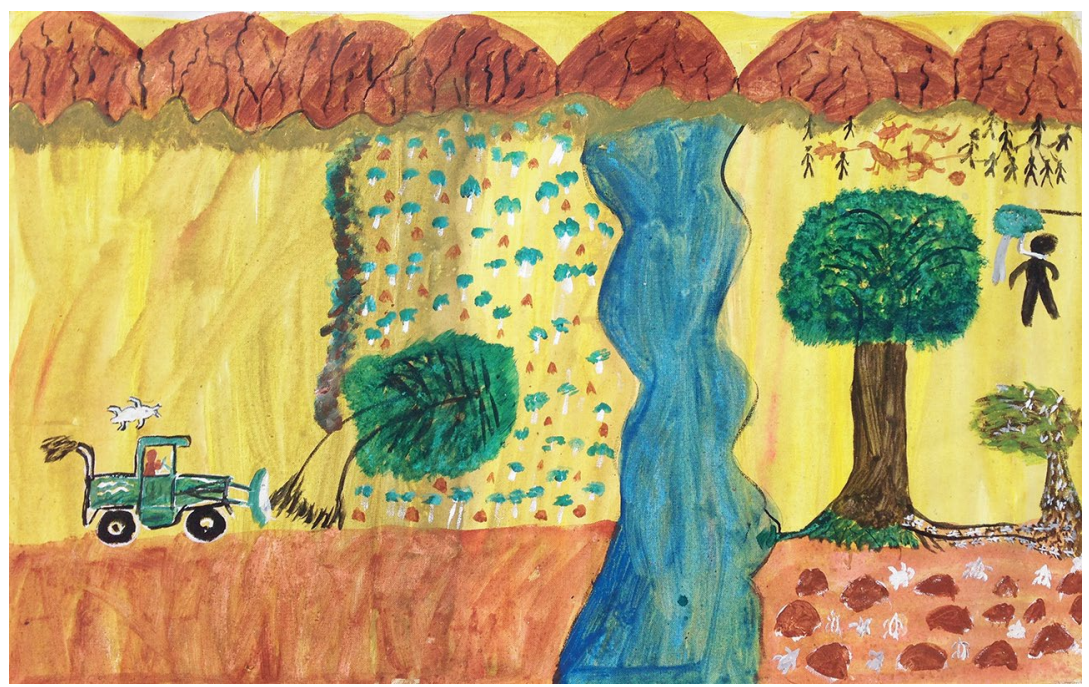

Fig. 9.9 Whitefellas work like white ants, Jacky Green, 2014

Source: Private collection

He says:

I call this painting 'Whitefellas work like white ants' because it tells the story of how whitefellas force their development projects on us and our country.

On the left of the painting is the whitefella bulldozer pushing over what he thinks is just a tree. But it's not just a tree. It's a sacred site tied in with the songlines that run through our country. Above the bulldozer is a white ant. White ants destroy things. 
On the right of the painting I show how white ants attack and kill healthy trees. The white ants find the weak spot, like a decaying root, they get in there and slowly start eating the tree from the inside out until they kill it.

This is what whitefellas do to us Aboriginal people, when they want to get us to agree to one of their development projects. They find the weak ones in our cultural groups. They look after them. They use them to sell their plans, and to tell us there will be jobs and good things from the development project, but there never is. There're only problems that we Aboriginal people are left with.

This way of working always causes conflict amongst our people. It starts to eat away at us and our communities from the inside out, just like white ants do.

When they pick us Aboriginal people off and separate the weak ones from our cultural groups they killing us and our culture. I symbolise this in my painting by the body hung by the neck in the tree.

\section{Future opportunities}

What is needed in the southwest Gulf region, and other regions of Australia, to assist Indigenous peoples further develop their cultural and natural resource management activities and social enterprises, is greater recognition of their property rights. Not only to land, but property rights to their fisheries, water and mineral resources.

To ensure that development projects benefit Indigenous peoples, policy frameworks need to link access to federal, state and territory support for major development projects to real steps to secure direct and substantial Indigenous benefits.

There is an urgent need to invest in Indigenous governance so that Indigenous peoples can build confidence, skills and institutions for positive and productive engagement with other industry and NGO sectors.

There is an urgent need for Federal and Territory governments to develop long-term investment frameworks for Indigenous cultural and natural resource management initiatives to create employment, new partnerships and market opportunities for Indigenous peoples. 
There is also an urgent need for the completion of carbon farming methodologies for regions with rainfall under $600 \mathrm{~mm}$ per year, so that Garawa and Waanyi land owners can participate in new market opportunities which may assist them to further grow social enterprises across the region.

Finally, federal, state and territory governments should obtain Indigenous peoples' free, prior and informed consent before adopting and implementing legislative or administrative measures that may affect them.

\section{Conclusion}

We conclude with Jacky Green reflecting on Indigenous peoples' experiences in dealing with governments and their top-down policies.

Once the government cleared us off our lands by shooting us and putting chains around our necks and dragging us off. Then, long time later, they said 'Here's your land back, we don't need it'. That tall man he poured the sand through that old man's hands. That made us real happy and we began to move back home. Government gave us a bit of help to get back and set ourselves up. But you know what? They never really took those chains off from round our necks, 'cos now they slowly pullin' on them. They pullin' us off our lands again and yardin' us up like cattle in town. They pullin' us off our land by not giving us schooling, health and housing services on our homelands. They not helpin' us. They sayin' to the parents if you don't send your kids to school we gonna stop your money and send you to prison. But there aren't no schools, so the parents have to move off their country to live like white man in town with no culture (Jacky Green, Borroloola, 17 April 2012). 


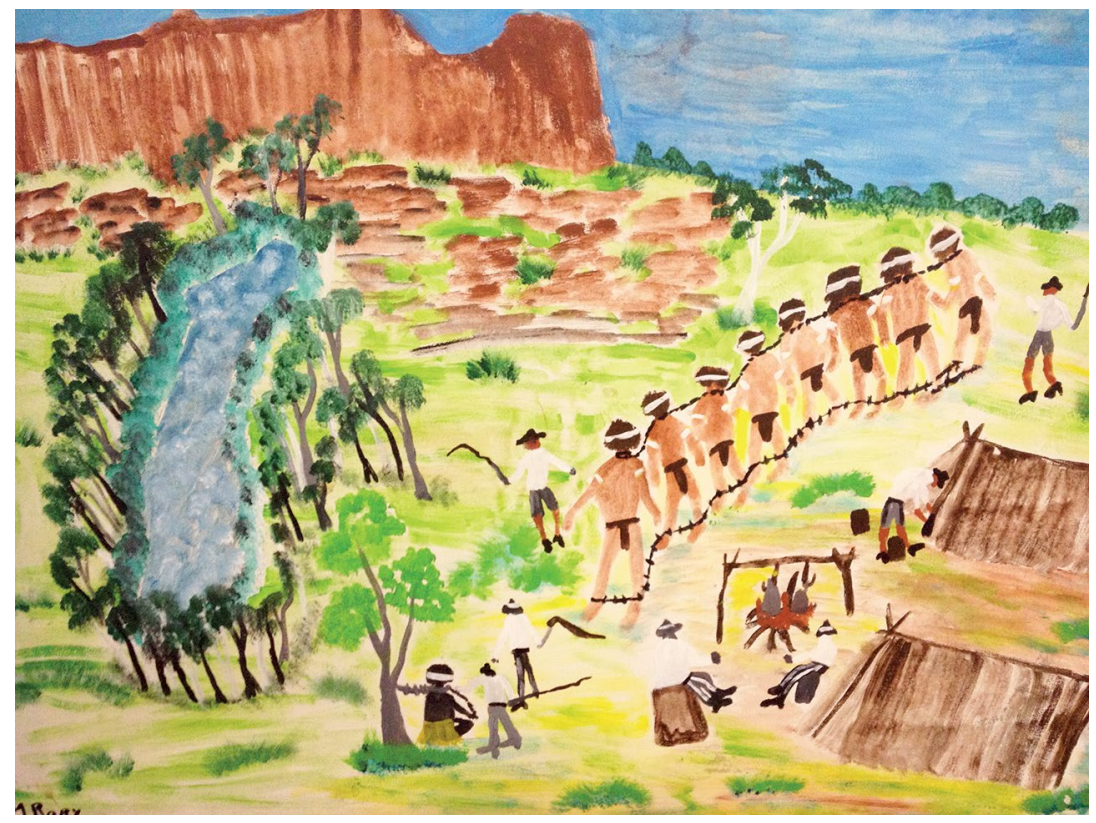

Fig. 9.10 Wundigala, Myra Rory, 2008

Source: Private collection

\section{References}

Altman JC (2011). The draft Indigenous Economic Development Strategy: a critical response, Topical Issue 3/2011, Centre for Aboriginal Economic Policy Research, The Australian National University, Canberra.

Baker R (1999). Land is life: from bush to town: the story of the Yanyuwa people, Allen \& Unwin, Sydney.

Bardon J (2014). McArthur River Mine's burning waste rock pile sparks health, environmental concerns among Gulf of Carpentaria Aboriginal groups. Australian Broadcasting Corporation, 27 July.

Berkes F \& Davidson-Hunt IJ (2007). Communities and social enterprises in the age of globalization. Journal of Enterprising Communities: People and Places in the Global Economy 1(3):209-21.

Bevage A (2013). Giles warns 'Lefty' stirrers. NT News, 24 June. 
Blaser M (2004). Life projects: Indigenous peoples' agency and development. In Blaser M, Feit HA \& McRae G (eds), In the way of development, Indigenous peoples, life projects and globalization, Zed Books, London, New York.

Borzaga C \& Defourny J (2001). The emergence of social enterprise, Routledge, London.

COAG (Council of Australian Governments) (2008). National Indigenous Reform Agreement (Closing the Gap), Australian Government, Canberra.

Forrest A (2014). The Forrest review: creating parity, Australian Government Department of the Prime Minister and Cabinet, Canberra.

Gambold N \& Kerins S (2013). Ganalanga Mindibirrina Indigenous Protected Area, Plan of Management, 2013-2018, Darwin.

Green J, Morrison J \& Kerins S (2012). 'No more yardin' us up like cattle'. In Altman JC \& Kerins S (eds), People on country: vital landscapes, Indigenous futures, The Federation Press, Sydney.

Kerins S (2012a). Building from the bottom-up: Indigenous development initiatives in the south-west Gulf of Carpentaria, Australia. In Proceedings of Nga Pae o te Maramatanga Conference, Auckland University, Auckland, New Zealand.

Kerins S (2012b). Caring for country to Working on Country. In Altman JC \& Kerins S (eds), People on country: vital landscapes, Indigenous futures, The Federation Press, Sydney.

Kerins S (2013a). A key role for Indigenous peoples in Australia's sustainable future. In Craven R, Dillon A \& Parbury N (eds), Black and White: Australians all at the crossroads, Connor Court Publishing, Melbourne.

Kerins S (2013b). Governing a Black commons. Indigenous Law Bulletin $8(8): 30-4$.

Northern Territory Government (2013). Indigenous Economic Development Strategy 2013-2020: frequently asked questions, Northern Territory Government, Darwin. 
Pearce J (2003). Social enterprise in Anytown, Calouste Gulbenkian Foundation, London.

Roberts T (2005). Frontier justice: a history of the Gulf Country to 1900, University of Queensland Press, St. Lucia, Queensland.

Thompson MJ (2005). Review of A Brief History of Neoliberalism. Democratiya 3(Winter):22-7.

Tudge A (2011). A new deal for Indigenous Australians. Institute of Public Affairs Review: A Quarterly Review of Politics and Public Affairs 63(4):20-3.

Wolfe P (2006). Settler colonialism and the elimination of the native. Journal of Genocide Research 8(4):387-409.

Yanyuwa Families and li-Anthawirriyarra Sea Rangers with Stephen Johnson (2011). Barni-Wardimantha Awara Yanyuwa Indigenous Protected Area Plan of Management and MERI Plan, Mabunji Aboriginal Resource Association, Borroloola, Northern Territory. 
This text is taken from Engaging Indigenous Economy: Debating diverse approaches, edited by Will Sanders, published 2016 by ANU Press, The Australian National University, Canberra, Australia. 